\title{
Seedcorn maggot, Delia platura (Meigen) (Insecta: Diptera: Anthomyiidae) ${ }^{1}$
}

\author{
Harsimran Kaur Gill, Gaurav Goyal, and Jennifer L. Gillett-Kaufman²
}

\section{Introduction}

The bean seed fly or seedcorn maggot, Delia platura (Meigen), is a small dipterous insect of the family Anthomyiidae (Valenciano et al. 2004). It is a sporadic pest with cosmopolitan distribution, (Higley and Pedigo 1984) on germinating seeds of many agronomic plants (Funderburk et al. 1984, Higley and Pedigo 1984). This fly is nearly identical to the cabbage maggot fly (Delia radicum) and the onion maggot fly (Delia antiqua), but it becomes active earlier. Previous names for this insect include: Hylemya platura, Hylemya cana, Hylemya cilicrura, Hylemya similis and others.

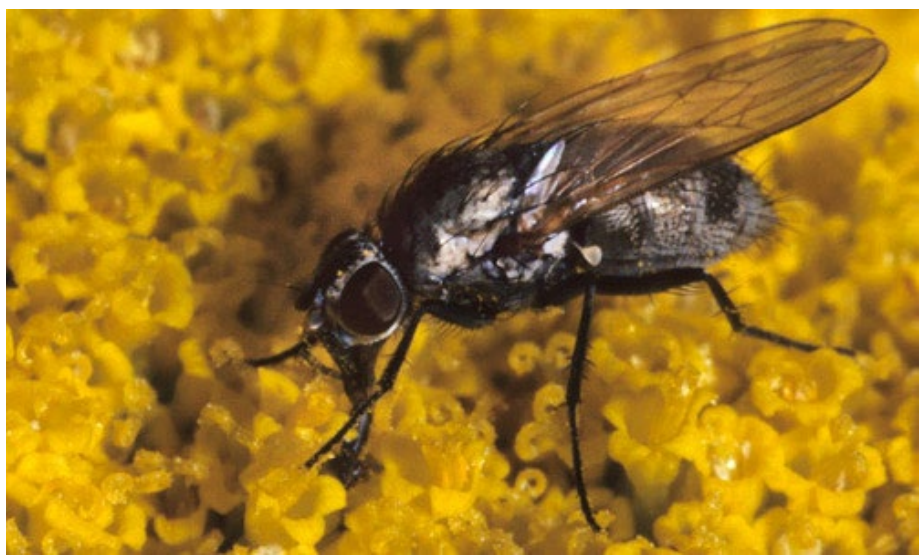

Figure 1. An adult bean seed fly, Delia platura (Meigen), on a flower. Credits: Leon Higley

\section{Distribution}

Delia platura is the most widespread anthomyiid (Weston and Miller 1989, Griffiths 1991) occurring on all continents except Antarctica (Griffiths 1991). First reported in Germany, it now is well established throughout the United States, including Alaska and Hawaii, and southern Canada (Gesell 2000). It is a major pest in North and South America as well as in Europe (Kornegay and Cardona 1991) and is found commonly in Japan, India, Australia, northern Africa, and New Zealand (Trotus and Ghizdavu 1996).

\section{Description}

Seedcorn maggot can pass through up to five generations per year (Gesell 2000, Harukawa et al. 1932, Higley and Pedigo 1984, Miles 1948) but only three are reported in Spain (Garcia et al. 1989). The time required to grow from egg to adult is three to four weeks, and a mean temperature of $74^{\circ} \mathrm{F}\left(23^{\circ} \mathrm{C}\right)$ for at least 24 to 25 days is required for completion of the life cycle (Strong and Apple 1958).

Eggs: The eggs are white, elongated, $1 / 16$ in $(0.16 \mathrm{~cm})$ long, and deposited in loose groups among the debris and around plant stems near the soil surface. The flies mate within two to three days after emerging, and each female lays an average 270 eggs in soil with abundant decaying organic matter and/or on seeds or plantlets in moist soil (Bennett et al. 2011). The eggs hatch after two to four days at temperatures as low as $50^{\circ} \mathrm{F}\left(10^{\circ} \mathrm{C}\right)$. Females lay eggs

1. This document is EENY566, one of a series of the Entomology and Nematology Department, UF/IFAS Extension. Original publication date July 2013. Visit the EDIS website at http://edis.ifas.ufl.edu.

2. Harsimran Kaur Gill, post doc research associate; Gaurav Goyal, post doc research associate; and Jennifer Gillett-Kaufman, assistant Extension scientist; Entomology and Nematology Department, University of Florida, Gainesville, FL 32611. 
near food resources and appear to be stimulated to oviposit by olfactory cues (Barlow 1965), which are produced by microbes from larval food sources (Eckenrode et al. 1975). Seedcorn maggots deposited significantly more eggs near the base of newly emerged seedlings when given a choice of five different stages of developing soybeans (Ibrahim and Hower 1979).

This pest is closely associated with organic matter such as manure and plant residues. Reports of actively feeding seedcorn maggots increase during years when the spring is comparatively cool and damp and seeds germinate slowly (Reid 1936, Miller and McClanahan 1969). Decaying organic matter from crop residues in reduced-tillage systems is an ideal ovipositional site for this insect (Barlow 1965, Gregory and Musick 1976)

Larvae: The legless larvae (maggots) are dirty white with a yellow tint, cylindrical and tapered in shape. Fully grown maggots are $1 / 5-1 / 4$ in $(0.50-0.63 \mathrm{~cm})$ long and have a pointed head with two black mouth hooks. The abdomen is blunt with two brown to black spiracles at the posterior end. The larval period lasts nearly 21 days (Bessin 2004), and the maggots develop over a large temperature range: $52^{\circ} \mathrm{F}$ to $92^{\circ} \mathrm{F}\left(11^{\circ} \mathrm{C}\right.$ to $\left.33^{\circ} \mathrm{C}\right)$. They complete their entire development within the soil by burrowing into seeds or feeding on cotyledons emerging from seeds (Bennett et al. 2011). Larvae of the seedcorn maggot can survive as soil saprophytes (Miller and McClanahan 1969), but they feed readily on seeds planted in infested soil (Funderburk et al. 1984).

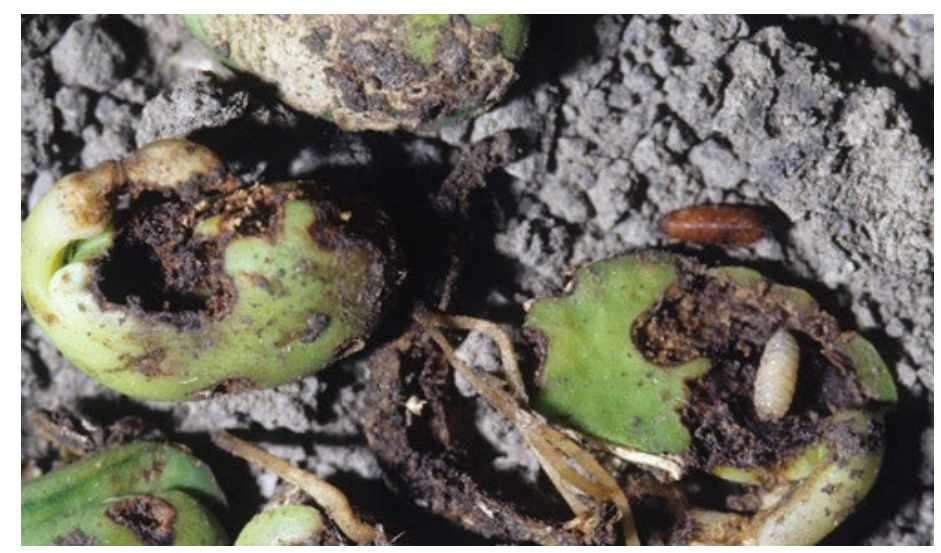

Figure 2. Late instar larva and pupa of the seedcorn maggot, Delia platura (Meigen), showing seed damage.

Credits: Leon Higley

Pupae: The puparia are 3/16-1/4 $(0.48-0.64 \mathrm{~cm})$ in long, dark brown to black, barrel shaped, and found in the soil near roots. The pupal stage requires at least 10 days until adults are ready to emerge (Gesell 2000). The seedcorn maggot survives the winter in the pupal stage in soil, and adults emerge in early spring (Higley and Pedigo 1984).
Aduts: The adults are brownish-gray flies resembling house flies, with three stripes on their back. They are half the size of a house fly, approximately $3 / 16-1 / 4(0.48-0.64 \mathrm{~cm})$ in long (Gesell 2000). The wings are held crossed over the abdomen at rest. Adult abundance of seedcorn maggots varies geographically and seasonally (Funderburk et al. 1984). In northern latitudes, adults are very numerous in the spring (two to three generations), but their population starts decreasing substantially in mid-summer (Eckenrode et al. 1973, Hagel et al.1981, Sanborn 1981). In the southern United States, adults are found commonly in the fall, early winter, and spring seasons, but few have been reported in mid-summer (Berisford and Tsao 1974, Reid 1940). Many seedcorn maggot adults die when the temperature exceeds $84^{\circ} \mathrm{F}$ (Harukawa et al. 1932).

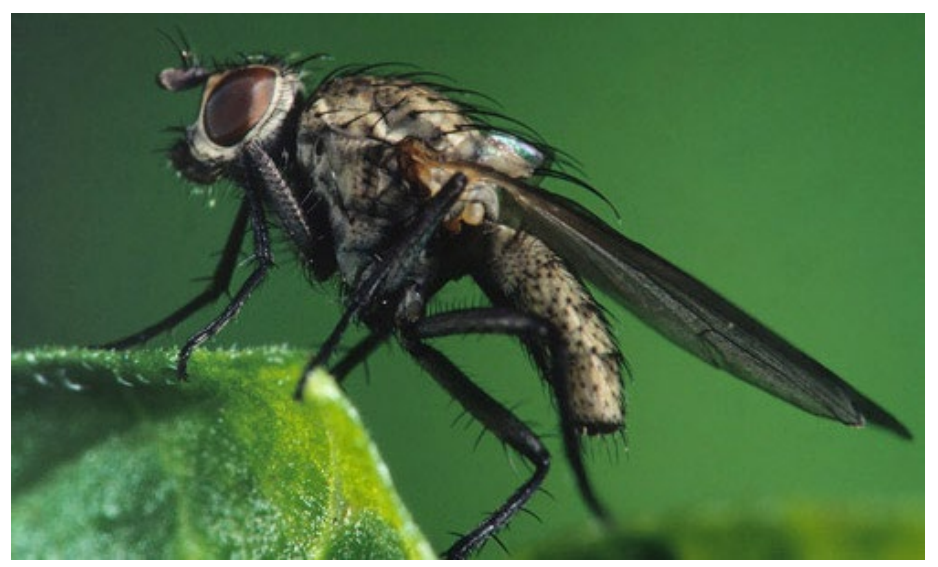

Figure 3. Adult bean seed fly, Delia platura (Meigen), on a leaf. Credits: Leon Higley

Given its worldwide distribution, this species must have some mechanism to escape from high temperatures. Females in temperate regions hide under wood and other sheltered habitats to avoid high temperatures, but there is no evidence of aestivation (Harukawa et al. 1932, Miles 1948, Strong and Apple 1958). In central Iowa, Funderburk et al. (1984) found that spring emergence of seedcorn maggot adults peaks in early June and flies completely disappear from late July until the next spring.

\section{Damage}

Bessin (2004) reported that seedcorn maggots damage newly planted seeds by feeding on seed contents, often leaving empty seed shells and preventing germination. Seedlings that germinate despite the damage are spindly, with few leaves, and die before maturation. Occasionally, seedcorn maggots tunnel within seedling stems and germinating seeds (Funderburk et al. 1983). Although usually no more than $2 \%$ of the seedlings get infested by this insect, $30 \%$ to $60 \%$ plant loss may occur in the field. Reduction in the plant stand can be seen within a week after plant 
emergence (Gesell 2000). Seedcorn maggot-induced damage is facilitated by early planting dates, heavy cover crops, and cool-wet weather (Bessin 2004).

In contrast to initial concerns, the adoption of conservation tillage practices has not increased seedcorn maggot injury. However, live, green organic matter or animal manure that is incorporated into the soil in the spring attracts egg-laying flies. The damage potential is minimal in no-tillage fields, and germinating seeds alone are not sufficient to attract large populations of egg-laying flies (Rice 1993).

\section{Host Plants}

The seedcorn maggot is a polyphagous pest, affecting more than 40 different host plants (Ristich 1950). It is an important pest of germinating soybeans and corn (Funderburk et al. 1983, Bessin 2004). It also attacks a wide range of horticultural crops including beans (Phaseolus spp.), peas (Pisum spp.), cucumber (Cucumis sativus), melon (Cucumis melo), onion (Allium cepa), pepper (Capsicum annuum), potato (Solanum tuberosum), and other vegetables (Kessing and Mau 1991).

Seedcorn maggot also feeds on other crops such as alfalfa (Medicago sativa), cotton (Gossypium spp.), strawberry (Fragaria ananassa), tobacco (Nicotiana tabacum), and wheat (Triticum aestivum). However, it often is considered a secondary pest or even saprophagous because it is associated with plants that have already been damaged by other insects and diseases (Brooks 1951, Griffiths 1986a, 1986b). Seedcorn maggot adults discriminate between different proteins sources and plant species (McLeod 1964, Ching-Chieh et al. 1975). For instance, a field study showed that germinating snap beans (Phaseolus vulgaris) attracted more female flies than did lima beans (Phaseolua lunatus) or unplanted areas (Ching-Chieh et al. 1975).

\section{Management}

Biological Control: Much of the seedcorn maggot's life cycle is passed protected underground, so it does not appear to have many reported natural enemies. Isolated incidences of predation by spiders, ants, and birds upon adults and of fungal diseases infecting larvae have been reported. However, none of these predators or pathogens is considered significant in controlling populations of seedcorn maggots (Reid 1940).

Cultural Control: Bessin (2004) reported preventative measures for seed corn maggots that include late planting, shallow planting, higher seeding rates, well-prepared seedbed, and turning the cover crops early (which renders field less attractive to egg laying by flies). Gessell (2000) recommended planting the field after 450 growing degree days since the ploughing of organic matter which allows seed corn maggots to complete development and move to another host. No-till fields are less likely to have seedcorn maggot problems because the germinating seeds alone are not sufficient to attract large populations of egg-laying females (Pope 1998). Kessing and Mau (1991) recommended aging the manure and incorporating it thoroughly in soil before planting. It was also recommended to drag a chain behind the planter to remove any seed row moisture gradient which otherwise could attract oviposition by adult flies. Attractiveness of an area for oviposition can also be reduced by removal of nearby food sources like flowering weeds and sweet-smelling substances from surrounding areas. Care should be exercised since this would also impact the availability of nectar for beneficial insects.

Chemical Control: Seed treatment has been reported as the cheapest and most effective treatment for the control of seedcorn maggots. Granular insecticide can also be used effectively for the control of these maggots (Kessing and Mau 1991). In beans plots, populations of seedcorn maggots can be managed best by choosing correct pesticide applications (can be applied either to seed or seedling line) and by following planting techniques mentioned in the cultural control section (Valenciano et al. 2004).

\section{Selected References}

Barlow CA. 1965. Stimulation of oviposition in the seed-corn maggot fly, Hylemya cilicrura (Rond.) (Diptera: Anthomyiidae). Entomologia Experimentalis et Applicata 8: 83-95.

Bennett KVW, Burkness EC, Hutchison WD. 2011. Seed corn maggot. Vegetable IPM Resource for the Midwest. University of Minnesota. (16 June 2013)

Berisford YC, Tsao CH. 1974. Field and laboratory observations of an entomogenous infection of the adult seedcorn maggot, Hylemya platura (Diptera: Anthomyiidae). Journal of the Georgia Entomological Society 9:104-110.

Bessin R. 2004. Corn: Cool soils favor damage by some insect pests. Kentucky Pest News. Number 985. (16 June 2013).

Brooks AR. 1951. Identification of the root maggots (Diptera: Anthomyiidae) attacking cruciferous garden crops 
in Canada, with notes on biology and control. Canadian Entomologist 83: 109-120.

Ching-Chieh Y, Webb DR, Kuhr RJ, Eckenrode CJ. 1975. Attraction and oviposition stimulation of seedcorn maggot adults to germinating seeds. Environmental Entomology 4: 545-548.

Eckenrode CJ, Gauthier NL, Danielson D, Webb DR. 1973. Seedcorn maggot: seed treatments and granule furrow applications for protecting beans and sweet corn. Journal of Economic Entomology 66: 1191-1194.

Eckenrode CJ, Harmon GE, Webb DR. 1975. Seed-corn microorganisms stimulate seedcorn maggot egg laying. Nature 256: 487-488.

Funderburk JE, Higley LG, Pedigo LP. 1984. Seedcorn maggot (Diptera: Anthomyiidae) phenology in central Iowa and examination of a thermal-unit system to predict development under field conditions. Environmental Entomology 13: 105-109.

Funderburk JE, Pedigo LP, Berry EC. 1983. Seedcorn maggot (Diptera: Anthomyiidae) emergence in conventional and reduced- tillage soybean systems in Iowa. Journal of Economic Entomology 76: 131-134.

Garcia F, Ferragut F, Costa J, Laborda R. 1989. Plagas agricolas. II. Insectos Endopterigotos. Universidad Politecnica de Valencia. Valencia, Spain.

Gesell S. 2000. Seed corn maggot as a pest of field corn. Entomological notes, department of Entomology, Penn State University. (25 January 2013)

Gregory WW, Musick GJ. 1976. Insect management in reduced tillage systems. Bulletin of the Entomological Society of America 22: 302-304.

Griffiths GCD. 1986a. Phenology and distribution of Delia radicum (L.) (Diptera: Anthomyiidae) in canola fields at Morinville, Alberta. Quaestiones Entomologicae 22: 29-50.

Griffiths GCD. 1986b. Relative abundance of the root maggots Delia radicum (L.) and D. floralis (Fallen) (Diptera: Anthomyiidae) as pests of canola in Alberta. Quaestiones Entomologicae 22: 253-260.

Griffiths GCD. 1991. Flies of the Nearctic region. Volume VIII, Part 2, Number 7. Cyclorrhapha II (Schizophora: Calyptrate) Anthomyiidae. E. Schweizerbart'sche
Verlagsbuchhandlung (Nagele u. Obermiller), Stuttgart, Germany.

Hagel GT, Burke DW, Silbernagel MJ. 1981. Response of dry bean selections to field infestations of seedcorn maggot in central Washington. Journal of Economic Entomology 74: 441-443.

Harukawa C, Takato R, Kumashiro S. 1932. Studies on the seed-corn maggot. II Ber. Ohara Institute of Landwirtsch, Forsch 5: 457-478.

Higley LG, Pedigo LP. 1984. Seedcorn maggot (Diptera: Anthomyiidae) population biology and aestivation in central Iowa. Environmental Entomology 13: 1436-1442.

Ibrahim YB, Hower AA, Jr. 1979. Oviposition preference of the seed corn maggot for various developmental stages of soybeans. Journal of Economic Entomology 72: 64-66.

Kessing JLM, Mau RFL. 1991. Seed corn maggot, Delia platura (Meigen). Crop Knowledge Master. Department of Entomology, Honolulu, Hawaii. (16 June 2013).

Kornegay J, Cardona C. 1991. Breeding for insect resistance in beans. In: van Schoonhoven A. Voysest O. (Eds.), Common Beans: Research for Crop Improvement. CAB International/ CIAT, Wallingford, California, pp. 619-648.

McLeod DGR. 1964. Nutrition and reproductive behavior of the seed-corn maggot, Hylemyia cilicrura (Rond.)

(Diptera: Anthomyiidae). Entomologia Experimentalis et Applicata 7: 329-334.

Miles M. 1948. Field observation on the bean seed fly (seed corn maggot), Chortophila cilicrura Rond., and C. trichodactyla Rond. Bulletin of Entomology Research 38: 559-574.

Miller LA, McClanahan RJ. 1969. Life-history of the seedcorn maggot, Hylemya cilicrura (Rond.) and of H. liturata (Mg.) (Diptera: Anthomyiidae) in southwestern Ontario. Canadian Entomologist 92: 210-221.

Pope R. 1998. Pests of germinating corn and soybean. Iowa State University, Extension. IC-480: 65-66.

Reid WJ, Jr. 1936. Relation of fertilizers to seed corn maggot injury to spinach seedlings. Journal of Economic Entomology 29: 973-980. 
Reid WJ, Jr. 1940. Biology of seed-corn maggot in the coastal plain of the south Atlantic states. United States Department of Agriculture Technical Bulletin. 723. p. 43.

Rice M. 1993. Managing seed-attacking insects. Iowa State University, University Extension. (16 June 2013).

Ristich SS. 1950. Biology of seed-corn maggot, Hylemya cilicrura (Rondani), and preliminary studies on its control. Ph.D. dissertation, Cornell University, Ithaca, New York.

Sanborn SM. 1981. European corn borer management on snap beans; seedcorn maggot in relation to snap bean root rot; and seedcorn maggot development in relation to temperature. Ph. D. dissertation, University of Wisconsin, Madison. 124 pp.

Strong FE, Apple JW. 1958. Studies on the thermal constants and seasonal occurrence of the seed-corn maggot in Wisconsin. Journal of Economic Entomology 51: 704-707.

Trotus E, Ghizdavu I, Malschi D, 1996. Structura speciilor de muste din genul Delia, daunatoare culturilor de fasole. Problems Protection Plant 24: 35-39.

Valenciano JB, Casquero PA, Boto JA. 2004. Evaluation of the occurrence of bean plants (Phaseolus vulgaris L.) affected by bean seed fly, Delia platura (Meigen), grown under different sowing techniques and with different forms of pesticide application. Field Crops Research 85: 103-109.

Weston PA, Miller JR.1989. Ovipositional responses of seedcorn maggot, Delia platura (Diptera: Anthomyiidae), to developmental stages of lima bean. Annals of the Entomology Society of America 82: 387-392. 